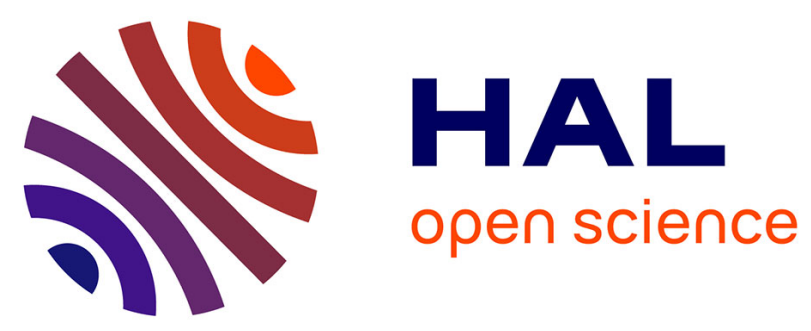

\title{
Nicotine stimulates maturational gonadotropin (Gth2) release from carp (Cyprinus carpio L.) pituitary cells
}

T. Mikolajczyk, Claudine Weil, Bernard Breton

\section{To cite this version:}

T. Mikolajczyk, Claudine Weil, Bernard Breton. Nicotine stimulates maturational gonadotropin (Gth2) release from carp (Cyprinus carpio L.) pituitary cells. Comparative Biochemistry and Physiology - Part C: Comparative Pharmacology and Toxicology, 1993, 105C (1), pp.83-88. 10.1016/07428413(93)90062-P . hal-02715927

\section{HAL Id: hal-02715927 \\ https://hal.inrae.fr/hal-02715927}

Submitted on 1 Jun 2020

HAL is a multi-disciplinary open access archive for the deposit and dissemination of scientific research documents, whether they are published or not. The documents may come from teaching and research institutions in France or abroad, or from public or private research centers.
L'archive ouverte pluridisciplinaire HAL, est destinée au dépôt et à la diffusion de documents scientifiques de niveau recherche, publiés ou non, émanant des établissements d'enseignement et de recherche français ou étrangers, des laboratoires publics ou privés. 


\title{
NICOTINE STIMULATES MATURATIONAL GONADOTROPIN $\left(\mathrm{GTH}_{2}\right)$ RELEASE FROM CARP (CYPRINUS CARPIO L.) PITUITARY CELLS
}

\author{
Tomasz MikolajczyK, ${ }^{*}$ Claudine Weil and Bernard Breton \\ Laboratoire de Physiologie des Poissons I.N.R.A., Campus de Beaulieu, 35042 Rennes, France and \\ *Department of Ichthyobiology and Fisheries, Agricultural Academy, 30149 Krakow-Mydlniki, Poland.
}

(Received 26 October 1992; accepted for publication 27 November 1992)

\begin{abstract}
Perifusion of dispersed pituitary cells and pituitary cell culture was used to investigate the effects of cholinergic drugs on the secretion of maturational gonadotropin $\left(\mathrm{GtH}_{2}\right)$ in carp.

2. Nicotine strongly, and in a dose dependent manner, stimulated $\mathrm{GtH}_{2}$ release in male and in female carp (from $10^{-8} \mathrm{M}$ in the perifusion and $10^{-10} \mathrm{M}$ in the cells cultures).

3. Nicotine is $\mathbf{1 0}$ times more active in females than in males.

4. The results suggest that in carp, nicotine stimulates $\mathrm{GtH}_{2}$ release directly from the pituitary cells, indicating a possible involvement of a cholinergic system in the regulation of $\mathrm{GtH}_{2}$ secretion in teleost fish.
\end{abstract}

\section{INTRODUCTION}

Maturational gonadotropin hormone $\left(\mathrm{GtH}_{2}\right)$ release in teleost fish is under complex neurohormonal and hormonal control. It is well established that in many teleost fish, including common carp (Cyprinus carpio L.) $\mathrm{GtH}_{2}$ secretion is stimulated by gonadotropin-releasing hormone (GnRH) (Breton and Weil, 1973; Sokolowska, 1982; Peter et al., 1986; Peter et al., 1987). On the other hand, dopamine (DA) acts as an endogenous inhibitor of spontaneous $\mathrm{GtH}_{2}$ release as well as an inhibitor of GnRH action at the pituitary level (Chang and Peter, 1983; Peter et al., 1986). The GnRH-DA system is not the only one which is implicated in the regulation of $\mathrm{GtH}_{2}$ release; recent studies have shown that in rainbow trout, goldfish and common carp neuropeptide Y (NPY) stimulates $\mathrm{GtH}_{2}$ secretion acting indirectly (through $\mathrm{GnRH}$ ) and also directly on the gonadotrophs (Breton et al., 1989; Breton et al., 1990; Peng et al., 1989; Breton et al., 1991). It has been recently shown that also other neurotransmitters such as GABA (Roelants et al., 1990; Kah et at., 1991), serotonine (Somoza et al., 1988) and opioids (Rosenblum and Peter, 1989) are involved in different ways in the regulation of the $\mathrm{GtH}_{2}$ secretion in fish. Up to now there are no data about the influence of the cholinergic system (cholinergic drugs) on the secretion of pituitary hormones in fish. In mammals acetylcholine $(\mathrm{ACh})$, muscarine, nicotine and their agonists stimulate or inhibit secretion of PRL, GH, ACTH and LH mainly through activation of peptidergic (GnRH, TRH) or aminergic (DA, NE) systems (for review, see Wilson, 1979; Brown et al., 1983; Gala, 1983). Specific cholinergic receptors have been found in the rat anterior pituitary gland (Schaeffer and Hsueh, 1980; Mukherjee et al., 1980), but their role in the regulation of pituitary hormone secretion is unknown. In the present study, using perifusion of dispersed pituitary cells and pituitary cells culture we have investigated the effect of different cholinergic drugs on the secretion of $\mathrm{GtH}_{2}$ from carp pituitary cells.

\section{MATERIALS AND METHODS}

\section{Experimental animals}

Experiments were conducted for two consecutive years (1989-90) during the natural reproductive period of carp. Sexually mature, 5-7 year old common carp (Cyprinus carpio L.) breeders (both sexes) weighing 5.5 to $11.5 \mathrm{~kg}$ obtained from Heyman Fish Farm were kept in natural earth ponds and then transported periodically to the laboratory. They were placed in a thermoregulated recirculating water system and acclimated at $20^{\circ} \mathrm{C}$ for at least one week before being used in experiments. They were exposed to controlled photoperiod $(16 \mathrm{~L}: 8 \mathrm{D})$ and fed ad libitum with pelleted food. Carps started to eat after 2-3 days of acclimation.

\section{Drugs}

All the drugs were purchased from Sigma, St. Louis, MO, U.S.A. $(-)$ Nicotine, Carbachol and Tetraethylammonim chloride (TEA) were dissolved directly in the perifusion or culture medium just prior to use. The $\mathrm{pH}$ of the test medium with nicotine was neutralized with $\mathrm{NaOH}$. Acetylcholine (ACh) and muscarine were dissolved as a $10^{-2} \mathrm{M}$ stock solution in sterile saline and diluted to the working concentrations in the perifusion or culture medium just before use. Eserine was first dissolved in pure ethanol and then to the final concentration in the test 
medium. The amount of ethanol never exceeded $0.01 \%(\mathrm{v} / \mathrm{v})$.

\section{Cell preparation and perifusion system}

Cell preparation and the perifusion system have been previously described in detail elsewhere (Mikolajczyk et al., 1990). Briefly, after enzymatical dispersion, cells were placed directly into the thermoregulated perifusion columns (max. of 5 columns could be used altogether). After equilibration time $(18 \mathrm{hr})$ cells were perifused at a flow rate of $15 \mathrm{ml} / \mathrm{hr}$. Fractions were collected every $7.5 \mathrm{~min}$ before and between drug application, and every $2.5 \mathrm{~min}$ during and $10 \mathrm{~min}$ after their administration. Details concerning each perifusion are given in the figure legends.

\section{Cell culture}

The protocol of carp pituitary cells dispersion was the same as for perifusion experiments. After dispersion the cells were resuspended in $2 \mathrm{ml}$ of culture medium. The culture medium consisted of MEM-Eagle (Gibco laboratories) buffered with $25 \mathrm{mM}$ Hepes and $9 \mathrm{mM}$ sodium bicarbonate. The medium had an osmotic pressure of $295 \mathrm{mOsm} / \mathrm{kg}$ and a $\mathrm{pH}$ of 7.45 , characteristic values of carp blood plasma. This culture medium was supplemented with $2 \%$ of serum substitute, Ultroser SF (IBF), $100 \mathrm{U} / \mathrm{ml}$ of penicillin, $10 \mu \mathrm{g} / \mathrm{ml}$ of streptomycin and $0.25 \mu \mathrm{g} / \mathrm{ml}$ of fungizone (Gibco). Cell counting and cell viability were determined in a Thoma hemocytometer. Viability of harvested cells was at least $90 \%$ as estimated by trypan blue dye exclusion. After counting, the cells were diluted to $2 \times 10^{5}$ cells $/ \mathrm{ml}$ of medium and $250 \mu 1$ of suspension (i.e. $5 \times 10^{4}$ cells) were plated in each well of 96-well plates (NUNC) precoated with $5 \mu \mathrm{g} / \mathrm{cm}^{2}$ of poly-L-lysine (Sigma). The dishes were maintained at $24^{\circ} \mathrm{C}$. After $60 \mathrm{hr}$ of culture the cells were washed twice with $250 \mu 1$ of ultroser and antibiotic-antimycotic free culture medium and subsequently reincubated in $250 \mu 1$ of this medium with or without tested drugs. All the treatments were tested in quadruplicate and all the experiments were repeated twice. After the removal of the incubation medium, samples were immediately centrifuged for $5 \mathrm{~min}$ at $3^{\circ} \mathrm{C}(200 \mathrm{~g})$, gently removed once again and frozen at $-25^{\circ} \mathrm{C}$ for ELISA.

\section{$\mathrm{Gt}_{2}$ determination and statistics}

$\mathrm{GtH}_{2}$ levels in a culture medium were determined using a specific ELISA developed by Kah et al. (1989). Concentration of $\mathrm{GtH}_{2}$ in a perifusion medium was measured using a specific RIA developed by Breton et al. (1971).

Profiles of $\mathrm{GtH}_{2}$ secretion from perifusion experiments are presented as a mean percentage of the basal $\mathrm{GtH}_{2}$ secretion level (b.l.). Basal level of $\mathrm{GtH}_{2}$ release $(100 \%)$ was calculated as a mean of the first four points (fractions) directly preceding first drug application. Fluctuations of $\mathrm{GtH}_{2}$ levels during the period directly preceding all drug administration never exceeded $18 \%$ of the basal $\mathrm{GtH}_{2}$ secretion level. Fluctuations in $\mathrm{GtH}_{2}$ secretion rate greater than $20 \%$ were considered as significant. In addition, signifcances between initial and stimulated $\mathrm{GtH}_{2}$ levels were checked using Duncan's multiple range test for variation analysis $(P<0.05)$. The data from cell culture experiments were analyzed using one-way analysis of variance followed by Tukey multiply range test at $P<0.05$ level of significance.

\section{RESULTS}

Effects of different cholinergic drugs on $\mathrm{GtH}_{2}$ secretion from perifused carp pituitary cells

As shown in Figs $1 \mathrm{a}$ and $1 \mathrm{~b}, 12.5 \mathrm{~min}$ application of increasing doses of nicotine provoked a dose dependent stimulation of $\mathrm{GtH}_{2}$ release in both sexes. In females (Fig. la) concentrations of nicotine of $10^{-8}, 10^{-7}$ and $10^{-6} \mathrm{M}$ increased the $\mathrm{GtH}_{2}$ secretion level by 39,122 and $521 \%$ respectively. In males (Fig. 1b) nicotine was about ten times less active than in females. At concentrations ranging from $10^{-8}$ up to $10^{-5} \mathrm{M}$ nicotine increased $\mathrm{GtH}_{2}$ secretion level of $0,26,145$ and $483 \%$ respectively. In both sexes, the cells began to respond to nicotine within $0-2.5 \mathrm{~min}$ after the beginning of the nicotine pulse. Maximal $\mathrm{GtH}_{2}$ levels were reached within 5-7.5 min, but $\mathrm{GtH}_{2}$ release began to decline rapidly while the secreta* gogue was still present in the perifusion chamber. Basal $\mathrm{GtH}_{2}$ levels recovered immediately after nicotine withdrawal.

Application of another cholinergic drug, muscarine, in a form of $12.5 \mathrm{~min}$ pulses at concentrations of $10^{-8}, 10^{-7}$ and $10^{-6} \mathrm{M}$ had no effect on $\mathrm{GtH}_{2}$ secretion in both sexes (Figs $2 a$ and $2 b$ ). However the highest dose $\left(10^{-5} \mathrm{M}\right)$ provoked a slight but signifcant increase in $\mathrm{GtH}_{2}$ release of $32 \%$ of baseline in females (Fig. 2a) and $36 \%$ in males (Fig. 2b). As shown in Fig. 3, a $12.5 \mathrm{~min}$ application of carbachol (ACh agonist) at a wide range of concentrations $\left(10^{-7}-10^{-5} \mathrm{M}\right)$ had no effect on $\mathrm{GtH}_{2}$ secretion level. Only the highest concentration $\left(10^{-4} \mathrm{M}\right)$ evoked a significant increase in $\mathrm{GtH}_{2}$ secretion of $43 \%$ in females (Fig. 3a) and $45 \%$ in males (Fig. 3b).

\section{The effects of different cholinergic drugs on $\mathrm{GtH}_{2}$} secretion from carp pituitary cells in culture

$\mathrm{GtH}_{2}$ release under the influence of nicotine was studied after $30 \mathrm{~min}, 1,3$, and $6 \mathrm{hr}$ of incubation. The stimulatory effect of nicotine on $\mathrm{GtH}_{2}$ release was observed in both sexes only after $30 \mathrm{~min}$ of incubation. Statistically significant differences $(P<0.05)$ between control and experimental groups were observed, starting from $10^{-10} \mathrm{M}$ concentration of nic* otine in females (Fig. 4) and $10^{-8} \mathrm{M}$ in males (Fig. 5). Stimulation of the cells for longer periods $(1,3$ and $6 \mathrm{hr}$ ) had no effect on $\mathrm{GtH}_{2}$ secretion neither in females nor in males (data not shown). Muscarine (data not shown) and acetylcholine alone or in the presence of eserine $\left(10^{-6} \mathrm{M}\right)$ at different concentrations and 

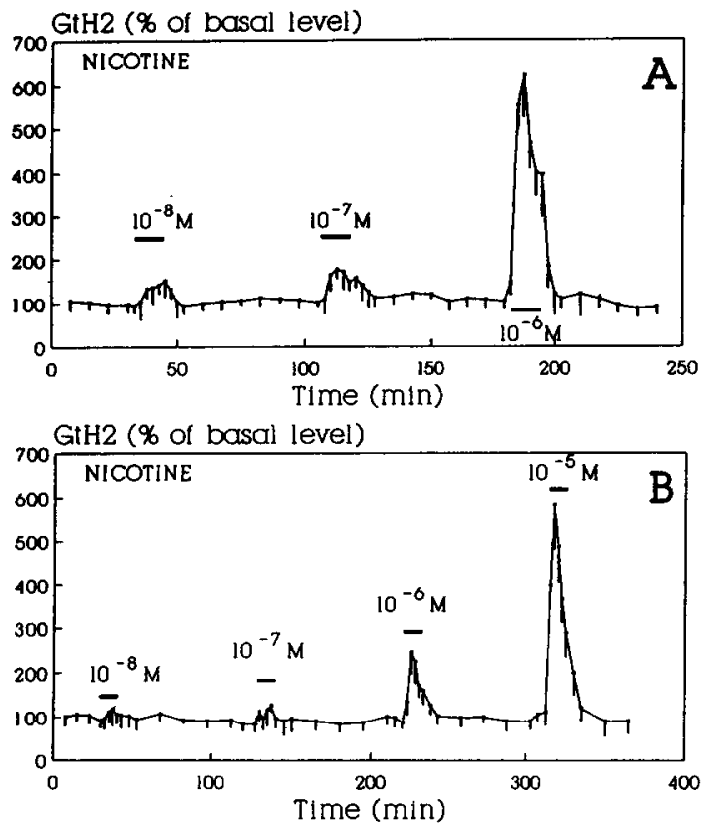

Fig. 1a. Effect of nicotine on $\mathrm{GtH}_{2}$ secretion from perifused female carp pituitary cells. Eight columns (data from two separate experiments) received three $12.5 \mathrm{~min}$ pulses of nicotine in concentrations of $10^{-8}, 10^{-7}$ and $10^{-6} \mathrm{M}$ as indicated. Mean basal $\mathrm{GtH}_{2}$ secretion level was $26 \pm 8 \mathrm{ng} / \mathrm{ml}$. 1(b). Effect of nicotine on $\mathrm{GtH}_{2}$ secretion from perifused male pituitary cells. Seven columns (data from two separate experiments) received four $12.5 \mathrm{~min}$ pulses of nicotine in concentrations of $10^{-8}, 10^{-7}, 10^{-6}$ and $10^{-5} \mathrm{M}$ as indicated. Mean hasal $\mathrm{GtH}_{2}$ secretion level was $15 \pm 6.5 \mathrm{ng} / \mathrm{ml}$.

after a different time of action had no effect on $\mathrm{GtH}_{2}$ release in females (Fig. 6) as well as in males (Fig. 7).

\section{DISCUSSION}

It has already been shown that in mammals the cholinergic system plays a role in the control of pituitary hormones secretion (PRL, GH, LH, ACTH), mainly indirectly through activation of different neurotransmitters system (for review, see Brown et al., 1983; Gala, 1983; Wilson, 1979; Hulihan-Giblin et al., 1990a and b; Calogero et al., 1989). Recently it was also demonstrated that cholinergic drugs act directly at the pituitary level. Thus, Rudnick and Dannies (1981) have shown an inhibitory action of ACh and muscarine on PRL secretion from rat pituitary cells in culture; however, other investigators (Campbell et al., 1978) demonstrated in the same species the lack of an effect of cholinergic agonists on PRL secretion. The most recent results of Lamacz et al. (1989) show that, in frogs, ACh stimulated $\alpha$-melanocyte-stimulating hormone release from pituitary fragments as well as from dispersed pituitary cells through activation of both nicotinic and muscarinic cholinergic receptors. The present investigations clearly show that nicotine induces an in vitro dose dependent stimulation of $\mathrm{GtH}_{2}$ release directly from carp pituitary cells. These results were obtained using perifused carp pituitary dispersed cells (dynamic model) as well as primary carp pituitary cells culture (static model). The stimulatory action of nicotine on $\mathrm{GtH}_{2}$ secretion was observed in both sexes; however its stimulatory effect was much stronger in females than in males (about 10 times in perifusion and about 100 times in static culture). It should be emphasized that nicotine action on $\mathrm{GtH}_{2}$ release is very sharp and short. In the perifusion system, during 12.5 min of nicotine application, $\mathrm{GtH}_{2}$ levels rise rapidly (first $5 \mathrm{~min}$ ) and then start to decline still in the presence of the drug, reaching basal secretion level by the end of nicotine application. A similar phenomenon was observed in static culture. The stimulatory effect of nicotine was seen after a short (30 min) stimulatory period only. This indicates a possible rapid and long-lasting desensitization of nicotine receptors in carp pituitary cells. From our point of view, it is also very important that, in our experiments, the stimulatory effect of nicotine was observed using very low concentrations of this drug; $10^{-10} \mathrm{M}$ in cultures and $10^{-8} \mathrm{M}$ in perifusions, versus $10^{-5}-10^{-4} \mathrm{M}$, and even higher in other works.

Surprisingly, in contrast to nicotine, acetylcholine (ACh) alone or in the presence of eserine, an acetylcholinesterase inhibitor, had no effect on $\mathrm{GtH}_{2}$ secretion from carp pituitary cells in culture as well as in perifusion (perifusion data not shown). Results obtained from the experiments with muscarine and with a nonhydrolizable ACh agonist-carbachol show their weak ability to stimulate $\mathrm{GtH}_{2}$ secretion in
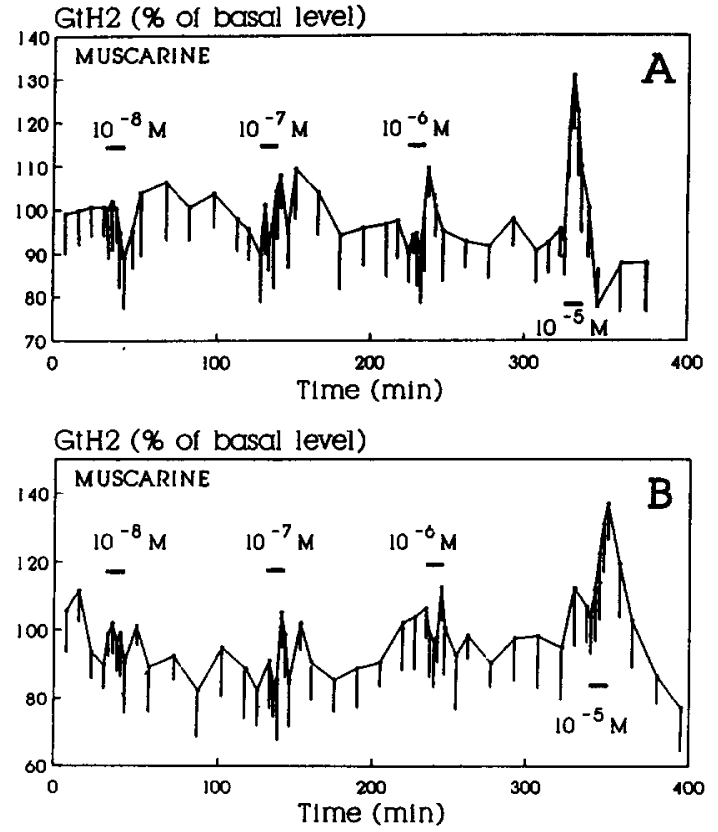

Fig. 2. Effect of muscarine on $\mathrm{GtH}_{2}$ secretion from perifused female (a) and male (b) carp pituitary cells. Muscarine in concentrations ranging from $10^{-8}$ up to $10^{-5} \mathrm{M}$ was administered in a form of $12.5 \mathrm{~min}$ pulses, as indicated. Each curve represents data from two experiments ( $n=8$ columns). 


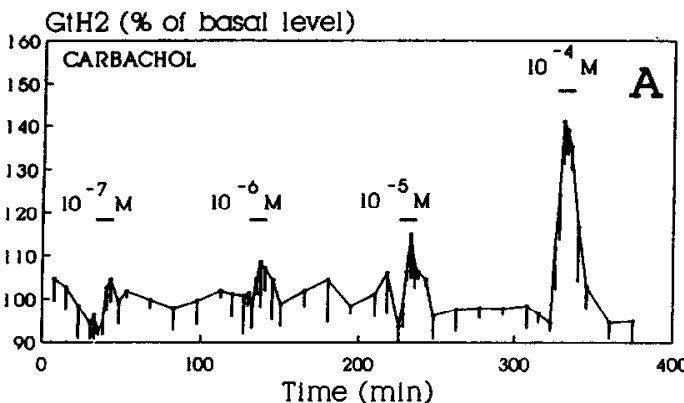

GtH2 ( $\%$ of basal level)

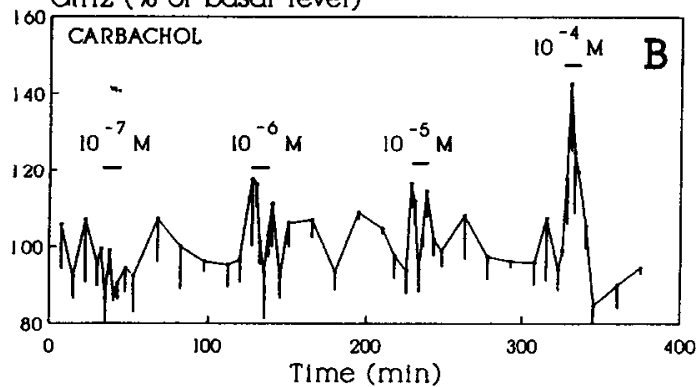

Fig. 3. Effect of carbachol on $\mathrm{GtH}_{2}$ secretion from perifused female (a) and male (b) carp pituitary cells. 12.5 min pulses of carbachol in concentrations ranging from $10^{-7}$ up to $10^{-4} \mathrm{M}$ were administered as indicated. Each curve represents data from two separate experiments ( $n=7$ columns).

comparison with nicotine. In the perifusion experiments, muscarine and carbachol at high concentrations $\left(10^{-5}\right.$ and $10^{-4} \mathrm{M}$ respectively) significantly increased the $\mathrm{GtH}_{2}$ secretion rate. However, their presence in a culture medium did not alter $\mathrm{GtH}_{2}$ secretion.

Taking together all the results presented above it is possible to conclude that nicotine stimulates $\mathrm{GtH}_{2}$ release acting directly at the pituitary cell level. Carbachol and muscarine also stimulates $\mathrm{GtH}_{2}$ secretion but in much higher concentration than nicotine. This lets us suppose that the cholinergic system is implicated in the direct control of $\mathrm{GtH}_{2}$ secretion

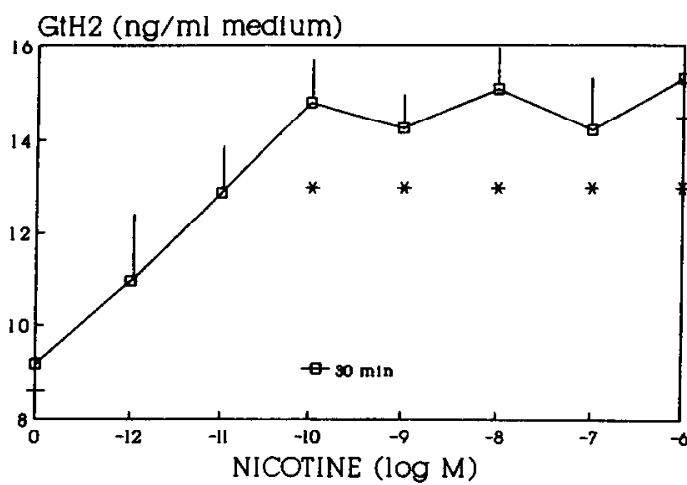

Fig. 4. Effect of nicotine on $\mathrm{GtH}_{2}$ release from female carp pituitary cells in culture ( $30 \mathrm{~min}$ stimulation period). Data from two separate culture experiments. Each point represents the mean $\pm \operatorname{SEM}(n=8)$.,$P<0.05$ vs control.

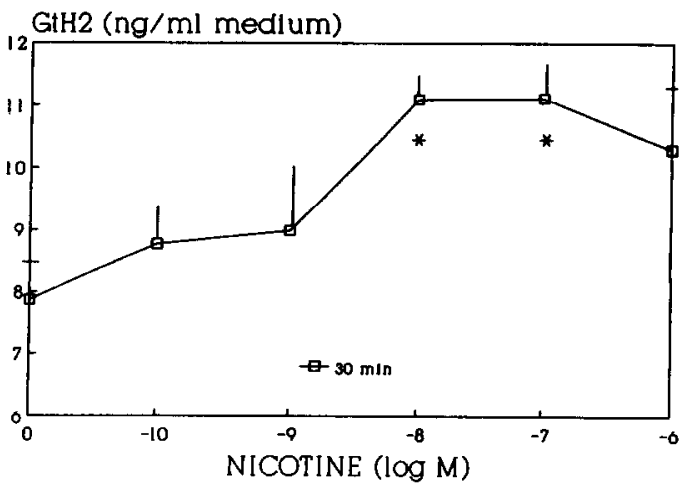

Fig. 5. Effect of nicotine on $\mathrm{GtH}_{2}$ release from male carp pituitary cells in culture. $30 \mathrm{~min}$ stimulation period. Data from two separate culture experiments. Each point represents the mean $\pm \operatorname{SEM}(n=8) . *, P<0.05$ vs control.

in carp. This is strongly supported by the fact that high acetylcholinesterase activity has been recently detected in carp pituitary gland and brain (Sokolowska, unpublished).

It is well known that in mammals, $\mathrm{ACh}$ action is mediated by two types of cholinergic receptorsmuscarinic and nicotinic. Up to now there is no clear evidence for existence of the same types of $\mathrm{ACh}$ receptors in fish. Possible differences in the structure

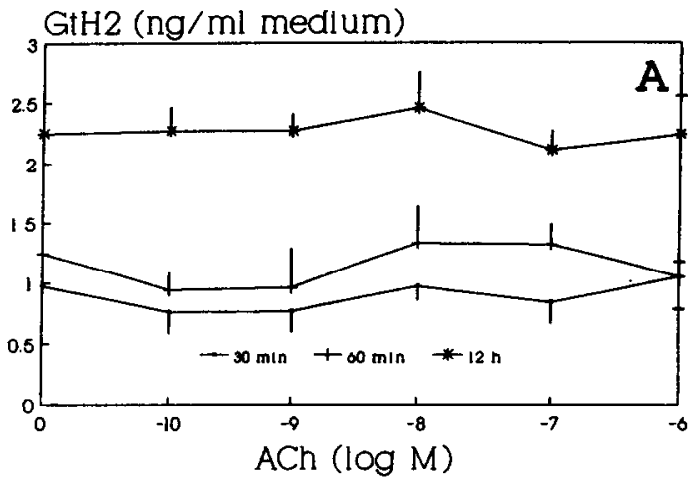

$\mathrm{GtH} 2$ (ng/ml medium)

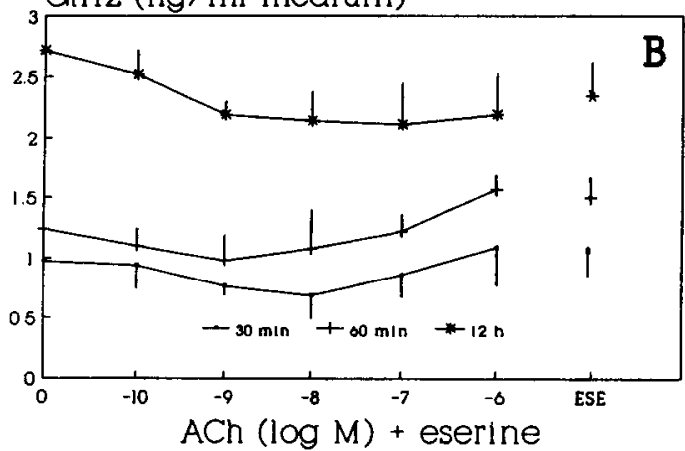

Fig. 6. Effect of acetylcholine (ACh) (A) and acetylcholine with eserine (B) on $\mathrm{GtH}_{2}$ release from female carp pituitary cells in culture. The cells were incubated with different concentrations of $\mathrm{ACh}$ alone or with $\mathrm{ACh}+$ eserine $\left(10^{-6} \mathrm{M}\right)$ for $30 \mathrm{~min}, 60 \mathrm{~min}$ and $12 \mathrm{hr}$. ESE = eserine alone $\left(10^{-6} \mathrm{M}\right)$. Data from two separate culture experiments. Each point represents the mean $\pm \operatorname{SEM}(n=8)$. 
$\mathrm{GtH} 2$ ( $\mathrm{ng} / \mathrm{ml}$ medlum)

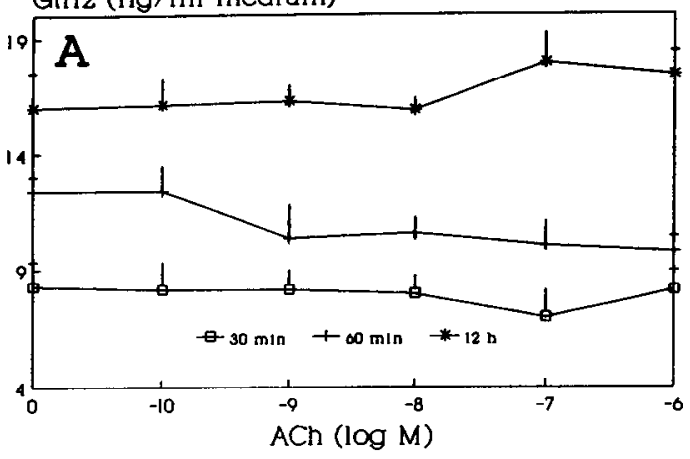

$\mathrm{GlH2}$ ( $\mathrm{ng} / \mathrm{ml}$ medium)

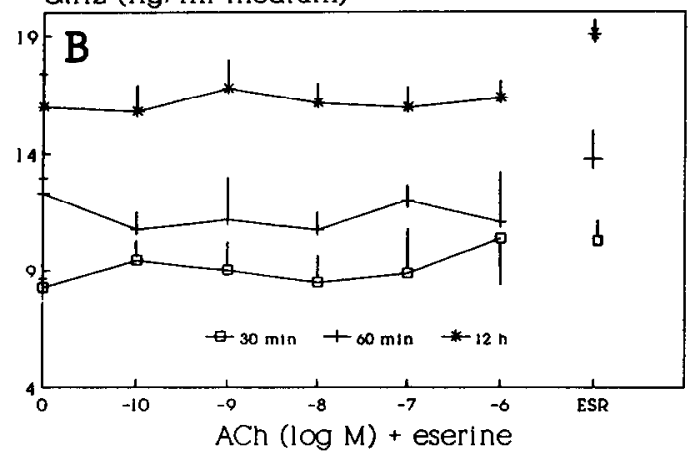

Fig. 7. Effect of acetylcholine (ACh) (A) and acetylcholine with eserine (B) on $\mathrm{GtH}_{2}$ secretion from male carp pituitary cells in culture. The cells were incubated with different concentrations of $\mathrm{ACh}$ alone or with $\mathrm{ACh}+$ eserine $\left(10^{-6} \mathrm{M}\right)$ for $30 \mathrm{~min}, 60 \mathrm{~min}$ and $12 \mathrm{hr}$. ESE = eserine alone $\left(10^{-6} \mathrm{M}\right)$. Data from two experiments. Each point represents the mean $\pm \operatorname{SEM}(n=7)$.

and the activity of cholinergic receptors between mammals and fish could partially explain why $\mathrm{ACh}$ and carbachol were less active in the stimulation of $\mathrm{GtH}_{2}$ secretion in comparison with nicotine. Another possible explanation could be that nicotine activates its own non-cholinergic receptors. Existence of such a type of nicotinic receptor has been already demonstrated in rat brain (Abood et al., 1979; Abood et al., 1980).

In summary, the present study demonstrates that nicotine strongly stimulates $\mathrm{GtH}_{2}$ release directly from carp pituitary cells. Other cholinergic drugs such as muscarine and carbachol also exert a stimulatory effect on $\mathrm{GtH}_{2}$ release. However their potency is much lower in comparison with nicotine. This indicates a possible involvement of the cholinergic system in the control of $\mathrm{GtH}_{2}$ secretion in teleost fish. Consecutive studies are already undertaken to demonstrate other aspects of cholinergic control of $\mathrm{GtH}_{2}$ secretion as well as to explain more precisely the discussed above phenomenon.

Acknowledgements-We are very grateful to Dr $M$. Sokolowska for critically reviewing the manuscript, and to Mr M. Gerber for the transport and care of fish. This work was made possible by a post-doctoral fellowship from INRA to T. Mikolajczyk.

\section{REFERENCES}

Abood L. G., Lowy K., Tometsko A. and MacNeil M. (1979) Evidence for a noncholinergic site for nicotine's action in brain: Psychopharmacological, electrophysiological and receptor binding studies. Archs. Int. Pharmacodyn. 237, 213-229.

Abood L. G., Reynolds D. T. and Bidlack J. M. (1980) Stereospecific ${ }^{3} \mathrm{H}$-nicotine binding to intact and solubilized rat brain membranes and evidence for its noncholinergic nature. Life Sci. 27, 1307-1314.

Breton B., Kann G., Burzawa-Gerard E. and Billard R. (1971) Dosage radio-immunologique d'une hormone gonadotrope de carpe (Cyprinus carpio L.). CR Acad. Sci. Paris, ser. D 272, 1515-1517.

Breton B., Mikolajczyk T., Danger J.-M., Gonnet F., Saint-Pierre S. and Vaudry H. (1989) Neuropeptide $Y$ (NPY) modulates in vitro gonadotropin release from rainbow trout pituitary glands. Fish Physiol. Biochem. 7, 77-83.

Breton B., Mikolajczyk T., Weil C., Danger J.-M. and Vaudry H. (1990) Studies on the mode of action of neuropeptide $\mathrm{Y}$ (NPY) on maturational gonadotropin (GtH) secretion from perifused rainbow trout pituitary glands. Fish Physiol. Biochem 8, 339-346.

Breton B., Mikolajczyk T., Popek W., Bieniarz K. and Epler P. (1991) Neuropeptide Y (NPY) stimulates in vivo gonadotropin secretion in teleost fish. Gen. Comp. Endocrinol. 84, 277-283.

Breton B. and Weil C. (1973) Effets d'extraits hypothalamiques de carpe et de LH/FSH-RH de synthese sur la secretion d'hormone gonadotrope c-GtH in vivo chez la carpe (Cyprinus carpio L.). CR. Acad. Sci. Paris, ser.D 277, 2061-2064.

Brown G. M., Cleghorn J. M. and Boyne T. S. (1983) Psychoneuroendocrinology of growth hormone: an update. In The Anterior Pituitary Gland (Edited by Bhatnagar A. S.) pp. 393-412. Raven Press, New York.

Calogero A. E., Kamilaris T. C., Gomez M. T., Johnson E. O., Tartaglia M. E., Gold P. W. and Chrousos G. P. (1989) The muscarinic cholinergic agonist arecoline stimulates the rat hypothalamic-pituitary-adrenal axis through a centrally-mediated corticotropin-releasing hormonedependent mechanism. Endocrinology 125, 2445-2453

Campbell M. D., Jacques S. Jr. and Gala R. R. (1978) The lack of an effect of cholinergic agonists on anterior pituitary prolactin production in vitro. Experientia 34, 1522-1523.

Chang J. P. and Peter R. E. (1983) Effects of dopamine on gonadotrophin release in female goldfish, Carassius auratus. Neuroendocrinology 36, 351-357.

Gala R. R. (1983). Areas of controversy in the regulation of prolactin secretion: cholinergic control In The anterior Pituitary Gland (Edited by Bhatnagar A. S.) pp. 269-277. Raven Press, New York.

Hulihan-Giblin B. A., Lumpkin M. D. and Kellar K. J. (1990a). Acute effects of nicotine on prolactin release in the rat: agonist and antagonist effects of a single injection of nicotine $J$. Pharmac. exp. Ther. 252, 15-20.

Hulihan-Giblin B. A., Lumpkin M. D. and Kellar K. J. (1990b) Effects of chronic administration of nicotine on prolactin release in the rat: inactivation of prolactin response by repeated injections of nicotine. $J$. Pharmac. exp. Ther. 252, 21-25.

Kah O., Pontet A., Rodriguez J. N., Calas A. and Breton B. (1989) Development of an Enzyme-linked Immunosorbent Assay for goldfish gonadotropin. Biol. Reprod. 40, 68-73. 
Kah O., Trudeau V. L., Sloley B. D., Martinoli M. G., Chang J. P., Yu K. L. and Peter R. E. (1991) Implication of GABA in the neuroendocrine regulation of gonadotrophin release in the goldfish (Carrasius auratus). Proc. of the fourth Int. Symp. on the reproductive physiology of fish. Norwich, U.K., 57-59.

Lamacz M., Tonon M-C., Louiset E., Cazin L., Strosberg D. and Vaudry H. (1989) Acetylcholine stimulates $\alpha$-melanocyte-stimulating hormone release from frog pituitary melanotrophs through activation of muscarinic and nicotinic receptors. Endocrinology 125, 707-714.

Mikolajczyk T., Weil C., Epler P. and Breton B. (1990) Calcium jons as a mediator in GnRH action on gonadotropin release in the common carp (Cyprinus carpio L.). Reprod. Nutr. Develop. 30, 483-492.

Mukherjee A., Synder G., and McCann S. M. (1980) Characterization of muscarinic cholinergic receptors on intact rat anterior pituitary cells. Life Sci. 27, $475-482$.

Peng C., Huang Y. P and Peter R. E. (1989) Neuropeptide $Y$ stimulates in vitro growth hormone and gonadotropin release in the goldfish Carasius auratus. Abst. XII International Symposium on Comparative Endocrinology, Malaga, May 1989.

Peter R. E., Chang J. P., Nahorniak C. S., Omeljaniuk R. J., Sokolowska M., Shih S. H. and Billard R. (1986) Interaction of catecholamines and $\mathrm{GnRH}$ in regulation of gonadotropin secretion in teleost fish. Rec. Prog. Horm. Res. 42, 513-548.
Peter R. E., Habibi H. R., Marchant T. A. and Nahorniak C. S. (1987) Vertebrate gonadotropin-releasing hormones: Phylogeny and structure-function relationships. Ann. N Y. Acad. Sci. 519, 299-309.

Roelants I., Epler P., Mikolajczyk T., Breton B., Bieniarz K. and Ollevier F. (1990) A presumptive role for GABA in the stimulatory cffects of Des-Gly ${ }^{10}\left[\mathrm{D}-\mathrm{Ala}^{6}\right]$-LHRHethylamide and pimozide on the gonadotropin release in carp. Life Sci. 47, 1801-1812.

Rosenblum P. M. and Peter R. E. (1989) Evidence for the involvement of endogenous opioids in the regulation of gonadotropin secretion in male goldfish Carasius auratus. Gen. Comp. Endocrinol. 73, 21-27.

Kudnick M. S. and Dannies P. S. (1981) Muscarinic inhibition of prolactin production in cultures of rat pituitary cells. Biochem. biophys. Res. Commun. 101, 689-696.

Schaeffer J. M. and Hsueh A. J. W. (1980) Acetylcholine receptors in the rat anterior pituitary gland. Endocrinology 106, 1377-1381.

Sokolowska M. (1982) The influence of luteinizing hormone releasing hormone (LHRH) on serum gonadotropin levels and oocyte maturation in female carp (Cyprinus carpio) L.). Comp. Biochem. Physiol. 73a, 273-278.

Somoza G. M., Yu K. L. and Peter R. E. (1988) Serotonin stimulates gonadotropin release in female and male goldfish, Carasius auratus L. Gen. Comp. Endocrinol. 72, 374382.

Wilson C. A. (1979) Hypothalamic neurotransmitters and gonadotropin release. Oxford Rev. Reprod. Biol. 1, 383-471. 